\title{
Characterization of the specific energy consumption of electricity in the Portuguese sausage industry
}

\author{
J. Nunes ${ }^{1}$, P. D. Silva ${ }^{2}$, L. P. Andrade ${ }^{1}$ \& P. D. Gaspar ${ }^{2}$ \\ ${ }^{1}$ Agriculture school, Polytechnic Institute of Castelo Branco, Portugal \\ ${ }^{2}$ Department of Electromechanical Engineering, \\ University of Beira Interior, Portugal
}

\begin{abstract}
The sausage is an ancient food type that is nowadays considered as a delicatessen. Sausages are categorized within the deli sector as meat sub products. It is a food product preferred by consumers due to its nutritional value and organoleptic characteristics (wide range of flavours and textures). There are many types of sausages, with around 1200 different varieties (according to German classification), classified into types according to different criteria such as types of ingredients, consistency, and preparation (raw, cooked, pre-cooked, dry). In the UK, 196,152 metric tons of sausages were consumed during 2011, valued in $\$ 1.2$ billion, while in the US this value was around \$20.4 billion two years before. The heating and cooling processes during sausage production are indispensable technologies to ensure both the specific organoleptic characteristics and properties conservation through time. This paper characterizes the production process and the energy consumption of sausages processing industry in Portugal (20 industries) and discusses the average specific energy consumption (SEC) of electricity and its standard deviation. The average value of this indicator for the sample was 660 $\mathrm{kWh}_{\mathrm{e}}$ /ton raw material. The energy consumption of this type of industry is mainly that of electricity ( $82 \%$ ). Several electricity savings, estimated at $23.9 \%$, can be achieved by implementing simple practice measures in the refrigeration systems. Keywords: sausage industry, energy efficiency, refrigeration.
\end{abstract}




\section{Introduction}

The industrial sector is comprised of a diverse set of industries that are globally responsible for $38 \%$ a worldwide energy consumption and $36 \%$ of carbon dioxide emissions $\left(\mathrm{CO}_{2}\right)$ (Abdelaziz et al. [1]).

The main industries of this sector are manufacturing industries within which stands agrifood industries [2]. At the European level, the food industry represents a universe of 287,000 industries with 4.25 million direct jobs and had in 2010 a turnover of 1.017 billion euros [3].

In Portugal, the food industries follow the European trend, being also the largest group of manufacturing industries in the country (13.2\%). In 2011 it reached a business turnover of 9.340 million euros [4]. Within the food industry, the largest sector corresponds to the meat industry. In 2010 this sector was represented by 1159 industries with a turnover of 1.130 million euros, representing $12.3 \%$ of total volume sales volume of food industries [4].

The main products of the meat industry sector are the cured sausages. Based on the results of 2012, these industries produced 87.400 tonnes of cured sausages, representing $46.8 \%$ of all industrial production of meat products and corresponding to a turnover of 249.4 million euros [5]. In Portugal, as in many European countries, there has been an increased production of cured sausages. It was registered an increase of $10.6 \%$ in 2012 comparing with the previous year [6].

In general, industries in this sector use two types of energy: electricity and fossil fuels. The electricity is used primarily on operating the cooling systems to comply with food safety requirements due to the high degree of spoilage of meat $[2,7,8]$. In the particular case of cured sausages manufacture, about $25 \%$ of the total industrial energy is used for cooling and refrigeration processes, and $48 \%$ for food processing [9]. However, during the production period, the cooling systems can consume $45 \%$ to $90 \%$ of total electricity. In non-production periods (retention periods), they are responsible for all electricity consumption [10,11].

The energy consumption in sausage factories depends on various factors such as the type of production process, the size and structure of the product, the chemical and physical properties of raw materials, type technology used, the mechanization level of the factory and the usage of installed capacity [12]. In order to maintain a sausages industry competitive taking into account the rising of energy costs, it is necessary to have a good energy and environmental performance. Thus, these industries should use the best available techniques and production practices, with major emphasis for its energy efficiency [13, 14].

In general, for evaluating the energy efficiency of an industrial unit is common to use a normalized scale, often defined by the ratio of energy expended during production and the result obtained from such production [11, 15]. Thus, indicators of Specific Energy Consumption (electrical and heat) are obtained, that allow the evaluation of the performance of an industrial unit by comparison with indicators that belong to others units with the same category for similar activities and technologies [12].

There are some SEC values for these two types of energy in related literature, although they correspond to industrial units with different dimensions, level of 
technologic and world regions, which difficult a comparative analysis [16]. Nevertheless, the indicators allow to find the best practices and procedures for the reduction of energy consumption in this type of industry. Fritzson and Berntsson [16] estimated that in the energy consumption related with the cooling of meat products, it is possible to achieve $10 \%$ of energy savings in modern industries and $15 \%$ in the oldest ones.

In Portugal, the industrial food sector is made up mostly by micro, small and medium industries, that having energy intakes lower than 500 Tep do not require an evaluation of their energy performance. For this type of industries, it's not known the energy profile or the main features that contribute to its energy performance, with special attention to refrigeration systems.

The present study uses the results obtained in a set of 20 sausage factories located in central region of Portugal to assess the characteristics of energy consumption, with particular emphasis on electrical energy. Thus, the characteristics of the infrastructures, refrigeration systems, energy consumption, energy performance and potential savings of electricity it will be analyzed. Also it is presented a set of mathematical equations that relate the main parameters that influence the performance of cooling systems, such as: raw materials, cold rooms' volume, electricity consumption and the nominal compressors power.

\section{Material and methods}

In order to evaluate the profile of electricity consumption in processing industries of cured sausages and to characterize their cooling systems, audits were performed in 20 sausage factories located in central region of Portugal. Industries, named CS1 to CS20, do the same type of activity and have a similar production process.

The audits were developed in two phases. In the first phase, each company was visited for the purpose of filling in an inquiry with a set of pre-defined questions. Specifically, the following aspects composed the inquiry: i) identification and location of the facility; ii) infrastructure characterization; iii) characterization of the activities developed; iv) identification and characterization of the production process; v) identification and quantification of energy types; vi) characterization of the electricity tax and its consumption; vii) disaggregation of consumption by sector and equipment; viii) characterization of cold rooms; ix) determination of the environmental conditions inside and outside of industrial facility and within the cold rooms; $x$ ) identification and characterization of refrigeration systems; xi) characteristics of compressed air systems; xii) practice measures of energy efficiency already implemented.

In the second phase, industries were visited again but now with the objective of measuring the relevant parameters for its characterization. Thus, in this second stage and with the assistance of several measuring equipment, the following parameters were quantified: i) dimensions of cold rooms; ii) inside and outside rooms' temperatures and relative humidity; iii) electricity consumption of different equipment, in particular cooling systems. Air temperature and relative humidity were measured using digital multifunction equipment, Testo 435-2 with temperature $\left(-20\right.$ to $\left.+70^{\circ} \mathrm{C}\right)$ and relative humidity $(0-100 \%)$ probes with accuracy 
of $\pm 0.3^{\circ} \mathrm{C}$ and $\pm 2 \% \mathrm{RH}$, respectively. The inner dimensions of cold rooms were determined with an infrared rangefinder with a maximum range of 60 meters and an accuracy of $\pm 1 \mathrm{~cm}$.

Global consumption of industries as well as the partial energy consumption in refrigeration systems were measured using digital power analyzers, Elcontrol Energy Explorer, with a measuring range of $15-750 \mathrm{~V}$ and 20-1000 A with an accuracy of $0.53-2 \mathrm{~V}$ and $0.04-2 \mathrm{~A}$, respectively.

In order to evaluate the energy performance of the industries in this case study, the following three indicators were introduced: specific electrical energy consumption (SEC), usage of cold rooms' volume (UCR) and nominal power of compressors per cold rooms' volume (NPC).

The SEC is an energy indicator commonly reported in the literature to evaluate the energy efficiency of industrial facilities or economic sectors $[17,18]$. This indicator was recently used in the energy analysis in meat manufacturing industries [19], in horticultural industries [20], in cheese industries [21] and in agrifood sector [22] as well as in the development of computational tools for the energy efficiency assessment in the agrifood sector [23]. The SEC value is determined by eqn (1).

$$
S E C=\frac{E}{R M} \quad\left(\mathrm{kWh} / \mathrm{ton}_{\mathrm{RM}}\right)
$$

where $E$ represents the annual electricity consumption $(\mathrm{kWh})$, and $R M$ designates the annual amount of raw materials processed (ton ${ }_{R M}$ ).

Another indicator using in this work is the usage of cold rooms' volume (UCR). It is a physical indicator determined by eqn (2).

$$
U C R=\frac{R M}{V_{\text {total }}} \quad\left(\operatorname{ton}_{\mathrm{RM}} / \mathrm{m}^{3}\right)
$$

where $V_{\text {total }}$ indicates the total volume of cold rooms. This indicator helps to evaluate the greater or less usage of cold storage with consequent implications for the energy consumption level.

The third indicator was calculated as nominal power of compressors per cold rooms' volume (NPC) which is determined by eqn (3):

$$
N P C=\frac{P_{\text {total }}}{V_{\text {total }}} \quad\left(\mathrm{kW} / \mathrm{m}^{3}\right)
$$

where $P_{\text {total }}$ is the nominal electric power of all refrigeration compressors. With this indicator it is possible to quantify the cooling power installed per unit of cold room volume and therefore express the quality of the sizing/usage of cooling systems. The statistical analysis of all data collected was performed using the SPSS program. In the correlations development, the points that don't satisfy the Chauvenet's criterion were excluded from the sample [24]. 


\section{Results analysis and discussion}

The two phases of the survey carried out in the processing industries of cured sausages provided a wide range of about these industries, which stands out: the year of facilities construction, amount of raw materials processed annually, number of cold rooms; total volume of the rooms, annual electrical consumption, SEC, UCR and NPC indicators. This data is analyzed in detail in the following subsections along with other data collected.

\subsection{Facilities}

According to the survey, $45 \%$ of the sausage factories feature a covered area up to $1.000 \mathrm{~m}^{2}$ and $55 \%$ between 1000 and $2000 \mathrm{~m}^{2}$. Most of the plants have 11 to 20 years old $(50 \%)$ and 21 to 30 years old $(30 \%)$. The walls of buildings are mostly built in brick masonry. Only $20 \%$ of plants have building walls constructed with polyurethane panels. The largest constructive solution for building covers is the fibre cement sheets $(75 \%)$. In general, the zone between the cooling chambers ceiling and loft is not ventilated. Globally, were analysed 138 cold rooms, i.e. an average of 7 cold rooms per plant with an average volume of $67 \mathrm{~m}^{3}$. The construction characteristics of these cold rooms are divided in $45 \%$ of brickwork coated with cork panels or polyurethane panels (55\%) with thicknesses between 60 and $80 \mathrm{~mm}$. Some of the cold rooms of older facilities show clear signs of quality loss of the thermal insulation. Furthermore, the door seals of the cold rooms are damaged in its majority, and do not use any protection device to prevent from thermal entrainment in open door position.

\subsection{Refrigeration systems}

The sausage factories use four levels of temperature: freezing $\left(-18^{\circ} \mathrm{C}\right)$, cooling $(0$ $\left.6^{\circ} \mathrm{C}\right)$, controlled atmosphere $\left(14-26^{\circ} \mathrm{C}\right)$ and climate $\left(12^{\circ} \mathrm{C}\right)$. In general, these industries use cooling systems to perform the treatment and conservation of raw materials and processed products and to air conditioning in processing rooms and corridors.

As the required cooling capacities are small, due to the small quantity of products to cool and air volume to be conditioned, the type of refrigeration system preferred is the individual small refrigeration unit (condensing units or refrigeration plants with a compressor or small refrigeration plants).

The industries analyzed in this study use the following cooling systems: 31 vapour-compression refrigeration systems with one compressor (29\%), 29 condensation units $(27 \%), 18$ direct cooling circuit plants (17\%), 14 air treatment units with air-to-air heat pump (steaming and drying) (13\%), 12 air treatment mini-units (steaming and drying) (11\%) and finally 3 refrigeration systems of compact type $(3 \%)$.

Globally, the cooling systems contain 128 compressors: 29 hermetic type $(22.5 \%), 89$ semi-hermetic $(69.5 \%)$ and 10 of open type $(8 \%)$. The nominal electrical power of the industrial refrigeration compressors lies between $4 \mathrm{~kW}$ and $127 \mathrm{~kW}$. 
The operation time of the compressor has the following distribution: $41 \%$ have a running time between 21 and 40 years, $49 \%$ between 11 and 20 years and only $10 \%$ has a running time between 1 and 10 years. From these results it appears that a large number of compressors has a high operation time committing their energy performance. According to Coquinot and Chapon [25], the average life of most equipment used in cold systems production should be between 15 to 20 years (compressors, fans, air treatment units) and beyond this period their energy efficiency decreases.

The refrigeration systems use 107 condensers, all cooled by forced air. The most commonly refrigerants used are the R22, R404a and R134a. Throughout the fieldwork it was found that many compressors lacked of maintenance, had oil leakage, some condensers were dirty and clogged and were installed in short ventilated areas or near heat sources, and finally, the cooling systems had a large time of operation.

\subsection{Energy consumption}

The results show that all industries use two types of energy: electrical and fuel (propane gas and diesel). Some industries still use firewood to cure the sausages in flues. The electric energy is used to power the electrical equipment of which stands out cooling systems, such as compressors, evaporator fans, condensers, electric heaters, air treatment units, electric saws, grinders, mixers, filling machines, compressed air systems, lighting, pumps and office equipment. Fuels are burned in heat generators (boilers) for water heating to use in the process (cooking the cured sausages) or cleaning operations. Firewood is also used in the flues for steaming and drying operations.

The measured electric energy consumption of sausage factories lies between $13 \mathrm{MWh}$ and $673 \mathrm{MWh}$ with an average value of $127 \mathrm{MWh}$.

Figure 1 shows the individual and average electrical and fuels consumption from sausage factories of this study. The results show that the average annual

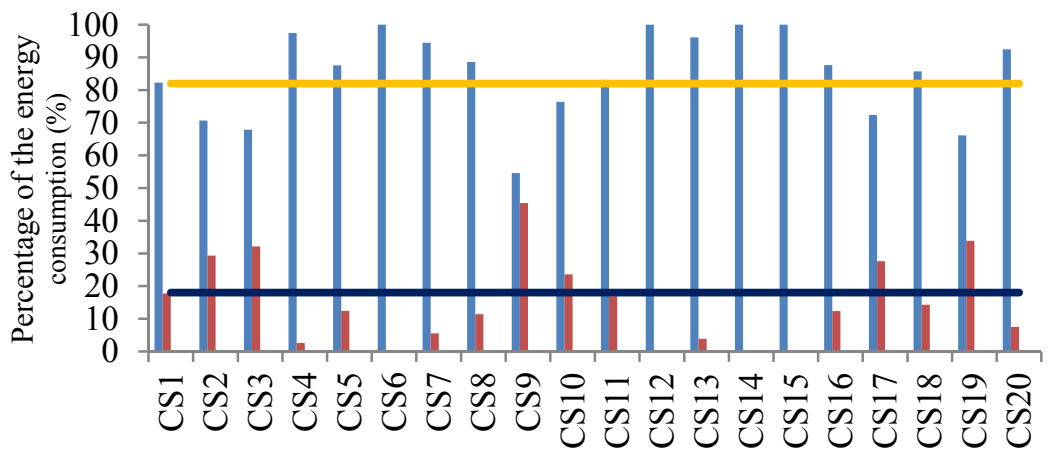

Sausage factories

Figure 1: Consumption profile of electrical and fuel in sausage factories. (口: Electricity; $\mathbf{\square}$ : Fuel; $\square$ : Average electricity; $\mathbf{\square}$ : Average fuel.) 
electricity consumption is $82 \%$ and the fuel consumption is $18 \%$. Some sausage factories only use electricity because they use electric water heating cylinder (CS6, CS12, CS14 and CS15).

In sausage factories, most of the equipment (grinder, mixers and fillers) only work during certain time periods of day or week. On the other hand, refrigeration systems work continuously most of the time. Globally, this set of industries consumed during the year, a total 667.4 tep distributed by 548.7 tep of electricity $(82 \%), 108.3$ tep of propane (16\%) and finally 12.4 tep of Diesel $(2 \%)$. In fact, electricity is the main type of energy used by the sausage factories.

The annual average electricity consumption by the main energy consumers of a typical sausage factory, processing 2066 ton of raw materials and consuming $1037 \mathrm{MWh}$ of electricity, is distributed by the refrigeration systems $(48.5 \%)$ and other electric equipment $(38.7 \%)$ as shown in Figure 2. However for smaller sausage factories with less activity, the distribution of consumption changes with cooling systems assuming even a greater share of the electricity consumption. For a sausage factory with an annual processing of 104,8 ton of raw materials and electric energy consumption of $4.4 \mathrm{MWh}$ the distribution of consumptions is $79.2 \%$ for cooling electrical systems, and $11.1 \%$ for electric motors. These results confirm that cooling systems are the major electricity consumers, as referred by Okos et al. [9], Pagan et al. [10] and Ramirez et al. [11].

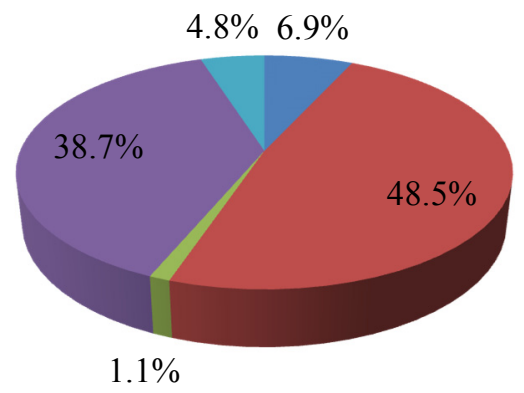

Figure 2: Distribution of electricity consumption for sausage factory - 2066 ton $_{\mathrm{RM}}$ and $1.037 \mathrm{MWh}_{\mathrm{e}}$ ( $\square$ : Refrigeration system; $\square$ : Motors;

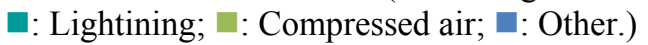

\subsection{Specific indicators}

The specific consumption of total energy (electrical and heat) of sausage factories of this study lies between $248 \mathrm{kWh} /$ ton and $2080 \mathrm{kWh} /$ ton. These results are higher than the values $(110-760 \mathrm{kWh} /$ ton) presented by benchmarking [26]. Figure 3 shows the value of SEC of sausage factories and its average for all the sausage factories industries analysed. The SEC is between 248 to $1840 \mathrm{kWh} /$ ton $_{\mathrm{RM}}$, with an average value of $660 \mathrm{kWh} / \mathrm{ton}_{\mathrm{RM}}$, within the range reported by Toresen et al. [27] and López et al. [28]. As it can be seen in Figure 4, there is a wide range of SEC value among the different industries. 


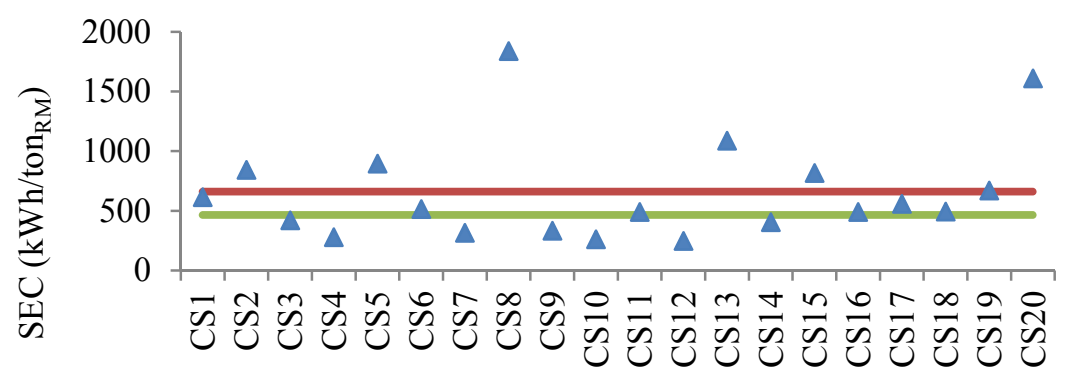

Figure 3: $\quad$ SEC values of sausage factories. ( $\triangle$ : SEC of sausage factories; -: average SEC; -: reference SEC.)

The sausage factory that has the lowest value of SEC, CS10, was constructed in 1995, and has the surroundings and cold rooms constructed in polyurethane panel with a thickness of $120 \mathrm{~mm}$ and the polyurethane cover with $40 \mathrm{~mm}$ panels. In addition, it also has a loft of identical height to the work zone $(4 \mathrm{~m})$ and is well ventilated. This industry also uses thermal energy from a boiler in air treatment units used in drying the cured sausages. It even has a program for managing the production activity, which consists of performing manufacture on certain days of the week and inactive in the remaining days in order to minimize the use of refrigeration systems. It has a direct-circuit cooling plant and maintenance plan of refrigeration systems. All these positive factors provide this industry with the lowest SEC value, $262 \mathrm{kWh} /$ ton $_{\mathrm{RM}}$. This result allows to conclude that the quality of the infrastructure materials, namely of walls, roof and cold rooms are a major factor in achieving these results. Furthermore, the energy use of thermal energy for the cure of sausages, and the use of centralized refrigeration equipment, with a good energy management and maintenance contribute to an improved energy efficiency.

The sausage factory that has the highest SEC value is CS8. The infrastructure of this sausage factory was built in 1994 with masonry and with a metal cover plate. The cold rooms are made of polyurethane panels with $60 \mathrm{~mm}$ thick. It also has an unvented loft, where temperature reach values higher than $50^{\circ} \mathrm{C}$. Furthermore, it has a compact cooling equipment installed inside the facility, resulting in heat dissipation of the condenser inside the facility as a result of a faulty location of the equipment. To maintain the interior environment of the climatic facilities, particularly of the processing room and hallways, the temperatures in these spaces are set to $8-10^{\circ} \mathrm{C}$ (below the standard temperature of $12^{\circ} \mathrm{C}$ ). This industry also works below its nominal capacity, with the lowest value of UCR, which is $0.15 \mathrm{ton} / \mathrm{m}^{3}$. On the other hand, it is also one of the industries that have the lowest NPC, $0.054 \mathrm{~kW} / \mathrm{m}^{3}$. Improper installation of refrigeration equipment and the use of low evaporation temperatures, combined with a large thermal load inside the facilities, force the cooling systems to present a high consumption of electrical energy. All these factors contribute to this industry present the largest SEC, $1840 \mathrm{kWh} /$ ton $_{\mathrm{RM}}$, far above the average of 660 $\mathrm{kWh} /$ ton $_{\text {RM. }}$. 
The set of factors described above are some examples that contribute to the result of the energy performance of sausages industries. These results allow to conclude that there are potential savings of electrical energy that can be achieved if the several inefficiencies detected were corrected. Assuming that all industries with a higher value than the average SEC (see Figure 3) implement practice measures to improve the energy efficiency in order to achieve this average value, it should be expected an overall potential of $24 \%$ of reduction consumption of electrical energy. In this case, the procedure presupposes sharing the best practices of energy use in this sector. This savings translates into an annual value of 337 MWh. In relation to the reference value [29], where the average value of the electrical energy consumption for the sausages processing is $465 \mathrm{kWh} / \mathrm{ton}_{\mathrm{RM}}$ (see Figure 3), the value of energy savings obtained is $37 \%$, corresponding to an annual value of $1813 \mathrm{MWh}$. It should be noted that the Spanish industries incorporate in the production process other forms of energy besides electricity [28], contrary to Portugal where the energy sources rely primarily on electricity and some biomass to perform the drying and smoking operations. This feature explains the large difference in electrical consumption observed between the industries of the two countries.

Figure 4 shows the UCR results. The UCR values show that not all sausage factories have a proper volume utilization of cold rooms in a similar manner. This result shows that the total installed capacity of sausage factories is not used (low UCR value). Consequently, sausage factories working below the nominal capacity show higher SEC values, meaning a decrease in their energy efficiency. For example, CS4, CS7, CS10, CS11, CS12 and CS14 have higher SEC values than CS2, CS8, CS13, CS15, CS17 and CS20. From this analysis it is concluded that for the activity of sausage factories, the partial load contributes to reduced energy efficiency. Globally, the average UCR value is $0.712 \operatorname{ton}_{R M} / \mathrm{m}^{3}$.

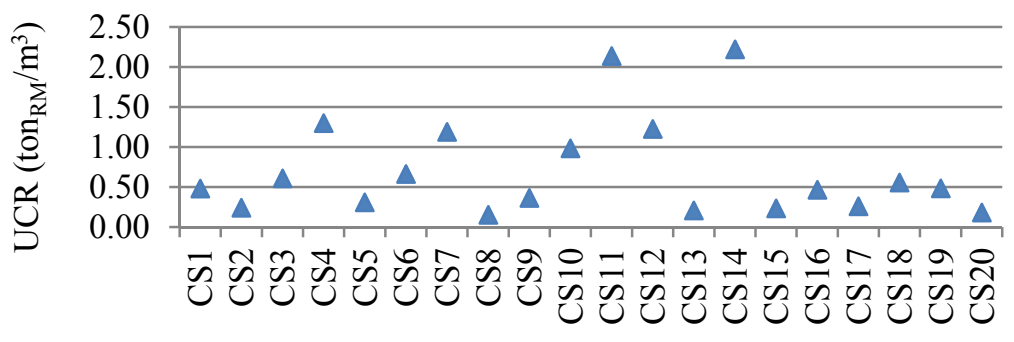

Sausage factories

Figure 4: UCR values of sausage factories.

Figure 5 shows the NPC results. It can be seen that there is a certain uniformity of results for this indicator, from which it can be concluded that the sizing or the cooling capacity used for activity of sausage factories presents certain standardization. Exceptionally, CS11 and CS14 have much higher values than the other sausage factories. However these two sausage factories also have the highest values UCR and the results are in agreement. Globally, the average NPC value is $0.1 \mathrm{~kW} / \mathrm{m}^{3}$. 


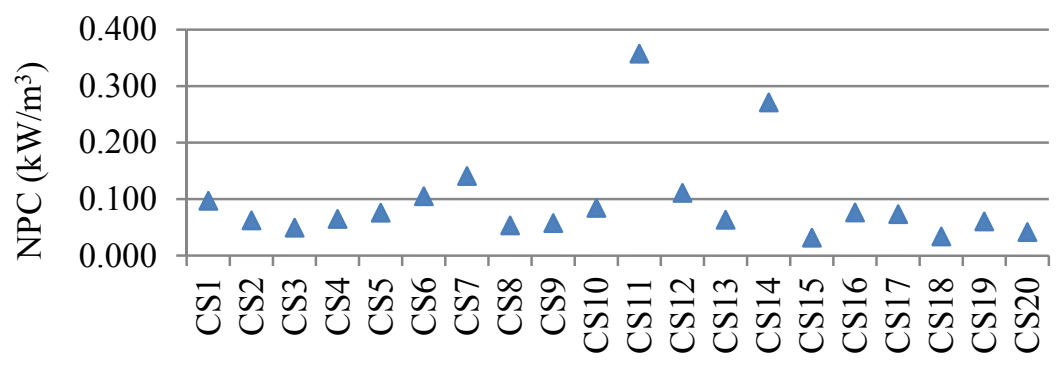

Sausage factories

Figure 5: NPC values of sausage factories.

\section{Conclusions}

In this study we have analyzed 20 sausage factories sector located in the centre region of Portugal. The analysis considers infrastructures, manufacturing processes, refrigeration systems, energy consumption, and evaluation of specific indicators. The sausage factories of this study, and generally in Portugal, are small industries that process annually an average value 255 ton of raw material, and have a covered area around $2000 \mathrm{~m}^{2}$. It are usually built of masonry and have fibrocement covering. The cold rooms are constructed of polyurethane panels with a 60 to $80 \mathrm{~mm}$ thickness and have an average volume of $67 \mathrm{~m}^{3}$.

The main type of energy used in this industry is electricity (82\%) and fuel in a smaller scale (18\%). The major electricity consumers are the refrigeration systems ( 48.5 to $79.2 \%$ of total electricity consumption).

The specific total energy consumption (electricity and heat) is between 248 $\mathrm{kWh} /$ ton and $2080 \mathrm{kWh} /$ ton. These results are higher than benchmarking considered as reference. Thus, the sausage factories in this study consume more energy. It must be highlighted that the consumption also depends manufacturing process.

The specific electrical energy consumption (SEC) value is between 248 to 1840 $\mathrm{kWh} /$ ton $_{\mathrm{RM}}$, with an average value of $660 \mathrm{kWh} /$ ton $_{\text {MR }}$. It is predicted that sausages industries that consume more energy than the average value, adapt best energy practices to reach that amount, would save approximately $24 \%$ of electricity equivalent to $337 \mathrm{MWh}$ annually. In relation to other literature, the savings would be $37 \%$ or equivalent to $1813 \mathrm{MWh}$ annually.

\section{References}

[1] Abdelaziz, E.A., Saidur, R., Mekhilef, S., A review on energy saving strategies in industrial sector. Ren. and Sust. Energy Rev 15, pp. 150-168, 2011.

[2] Wang, L., Energy Efficiency and Management in Food Processing Facilities. CRC Press, Boca Raton, FL, USA, 2008. 
[3] Fooddrinkeurope, Annual Report 2012. Food Drink Europe, Brussels, 2012.

[4] INE, Anuário Estatistico de Portugal 2010. INE, Lisbon, 2011 (portuguese).

[5] INE, Estatisticas da Produção Industrial 2009. Instituto Nacional de Estatistica, I.P., Lisboa, 2010 (in portuguese).

[6] INE, Indicadores económicos: Produtos produzidos na indústria por Tipo de produto (Por CAE Rev. 3); Anual INE, INE, Lisboa, 2013 (portuguese).

[7] Talon, R., Lebert, I., Lebert, A., Leroy, S., Garriga, M., Aymerich, T., Drosinos, E.H., Zanardi, E., Ianieri, A., Fraqueza, M.J., Patarata, L., Lauková, A., Traditional dry fermented sausages produced in small-scale processing units in Mediterranean countries and Slovakia. 1: Microbial ecosystems of processing environments. Meat Science 77, pp. 570-579, 2007.

[8] Toldrá, F., Hui, Y.H., HB fermented meat \& poultry. Blackwell Pub., 2007.

[9] Okos, M., Rao, N., Drecher, S., Rode, M., Kozak, J., Energy Usage in the Food Industry. American Council for an Energy-Efficient Economy, 1998.

[10] Pagan, R., Prasad, P., Price, N., Kemp, E., Eco-efficiency for the Queensland Food Processing Industry. Queensland Government, 2004.

[11] Ramírez, C.A., Patel, M., Blok, K., How much energy to process one pound of meat? A comparison of energy use and specific energy consumption in the meat industry of four European countries. Energy 31, pp. 2047-63, 2006.

[12] Wojdalski, J., drózdz, B., Grochowiez, J., Magrys, A., Ekielski, A., Assessment of Energy Consumption in a Meat-Processing Plant-a Case Study. Food Bioprocess Technology 6, pp. 2621-2629, 2013.

[13] EC, Integrated pollution prevention and control. Reference document on best available techniques in the slaughterhouses and animal by-products industries. European Commission (EC). Brussels, 2005.

[14] Pagan, R., Renouf, M., Prasad, P., Eco-Efficiency Manual for Meat Processing. Meat and Livestock Australia Ltd, Australia, 2002.

[15] Reindl, D.T., Jekel, T. B., Elleson, J.S., Industrial Refrigeration Energy Efficiency Guidebook. IRC, Industrial Refrigeration Consortium. The University Wisconsin, Madison, 2005.

[16] Fritzson, A., Berntsson, T., Energy efficiency in the slaughter and meat processing industry--opportunities for improvements in future energy markets. Journal of Food Engineering 77, pp. 792-802, 2006.

[17] Maxime, D., Marcotte, M., Arcand, Y., Development of eco-efficiency indicators for the Canadian food and beverage industry. Journal of Cleaner Production 14, pp. 636-648, 2006.

[18] Nanduri, M., Nyboer, J., Jaccard, M., Aggregating physical intensity indicators: results of applying the composite indicator approach to the Canadian industrial sector. Energy Policy 30, pp. 151-163, 2002.

[19] Nunes, J., Silva, P.D., Andrade, L.P., Energetic efficiency evaluation in refrigeration systems of meat industries in: IIR (Ed.), The 23rd IIR International Congress of Refrigeration. Refrigeration for Sustainable Development August 21-26, Prague, Czech Republic, 2011. 
[20] Nunes, J., Silva, P.D., Andrade, L.P., Gaspar, P.D., Dominuges, L.C., Energetic evaluation of refrigeration systems of horticultural industries in Portugal, 3rd IIR International Conference on Sustainability and Cold Chain (ICCC 2014), London, United Kingdom, June 23-25, 2014.

[21] Neves, D., Gaspar, P.D., Silva, P.D., Andrade, L.P., Nunes, J., Computational tool for the energy efficiency assessment of cheese industries - Case study of inner region of Portugal, $V$ Congreso Iberoamericano de Ciencias y Técnicas del Frío (CYTEF 2014), Tarragona, Spain, June 18-20 2014.

[22] Gaspar, P.D., Silva, P.D., Andrade, L.P., Nunes, J., Domingues, C., Assessment of the energy consumption in Portuguese agrifood industries, Energy Systems Conference, London, UK, June 24-25, 2014.

[23] Santos, R., Nunes, J., Silva, P.D., Gaspar, P.D., Andrade, L.P., Computational tool for the analysis and simulation of cold room performance in perishable products industry, $2^{\text {nd }}$ IIR International Conference on Sustainability and the Cold Chain (ICCC 2013), International Institute of Refrigeration (IIR), Paris, France, April 2-4, 2013.

[24] ASHRAE, Engineering Analysis of Experimental Data. ASHRAE Guideline 2. ASHRAE. Atlanta, 1986.

[25] Coquinot, J.P., Chapon, J.F. Entreposage frigorifique des pommes et des poires: equipement, 1. ed. Ctifl-Centre technique interprofessionnel des fruits et légumes, Paris, 1992.

[26] IFC, Environmental, Health, and Safety Guidelines for Dairy Processing. IFC-International Finance Corp. World Bank Grp. Washington, USA, 2007.

[27] Toresen, K., Kjött, N., Herlevsen, S., Pontoppidan, O., Hansen, P.I.E., Nordic slaughterhouses BAT document. The Danish Meat Research Institute, Roskilde, Denmark, 2001.

[28] López, A., Esnoz, A., Carles, B., Coronas, A., Estudi tecnològic del fred a la indústria agroalimentària i les seves millors tecnologies disponibles en consum d'energia. Institut Català d'Energia. Sociedad Espanola de Ciências y Técnicas del Frio, 2005.

[29] Singh, R.P., Energy Accounting of Food Processing Operations. In Energy in Food Processing (Ed R. Paul Singh) Elsevier, 1986. 